\title{
Variation in Morphology, Reproductive Allocation and Propagule Production of Poa annua L. in Arable Lands
}

\author{
Matsuo Itoh*, Hisao Kobayashi** and Kunikazu Ueki***
}

\begin{abstract}
Variation in morphology and energy allocation pattern to propagule output was analyzed in six Poa annua L. populations from paddy fields, upland fields and pathways in two locations to determine the adaptive strategies of the species to their habitats.

There was great variation among populations in seed number per plant and reproductive allocation (RA) or plant biomass. The number of seeds in all three populations from one of two locations increased in response to RA. Seed numbers of the paddy and upland field populations from the other location were independent of both RA and plant biomass. The remaining pathway population increased the seed number in response to both RA and plant biomass.
\end{abstract}

Paddy field plants headed slowly with a large number of leaves on the main stem. They produced large and heavy seeds and large plant biomass, causing rather low RA. In contrast, individuals from upland fields flowered quickly with a small number of leaves, putting out small and light seeds from their small plant biomass, which resulted in relatively high RA. Pathway plants showed intermediate characteristics between paddy field and upland field plants. The reproductive traits of upland field populations seem

* Agricultural Research Station, Monsanto Japan Ltd., Kawachi, Inashiki, Ibaraki 301-13, Japan.

** Faculty of Agriculture, Yamaguchi University, Yoshida, Yamaguchi 753, Japan.

*** The Ishikawa Agricultural College, 1-308 Suematsu, Nonoichi, Ishikawa 921, Japan.

(Received May 10, 1995) adaptive to the irregular ploughing in upland fields, and paddy field populations appear to be adaptive to the competition from other weeds or crops.

Key words : Poa annua L., adaptation, paddy field, reproductive allocation, upland field

\section{Introduction}

Poa annua L. is a colonizing species growing mainly in disturbed areas such as cultivated gardens, roadsides and pastures ${ }^{3,18}$. In Japan, this species has sometimes caused a serious problem to winter cropping in paddy and upland fields. Those two fields are quite different in cropping system : paddy fields in winter lie fallow or are cropped with wheat (Triticum aestivum L.) after rice is harvested, while upland fields are irregularly rotated with several vegetables or crops. Studies on the variation of $P$. annua in such varied cultivated lands are important for the control of this weed.

Evidence of wide variation of $P$. annua has been reported in such diverse habitats as turfgrass areas, pastures and disturbed sites $^{10,12,13,19)}$. Ecotypic differentiations within a species between paddy and upland fields have been documented in two grass species, Agropyron tsukushiense (Honda) Ohwi var. transiens (Hack.) Ohwi ${ }^{16)}$ and Alopecurus aequalis Sobol. var. amurensis (Komar.) Ohwi ${ }^{14)}$. Similar adaptive variation to these species is expected in $P$. annua populations from paddy and upland fields. 
Variation in reproductive capacity and energy allocation pattern to propagules is believed to be the result of selection pressures optimizing energy allocation to reproductive structure $^{1,2,4,6)}$. Intraspecific variation in energy allocation pattern has been studied for some species ${ }^{9,12,17,19)}$. Detailed analysis on energy allocation patterns of $P$. annua can provide invaluable information as to the adaptive modes of the species.

$P$. annua is ordinarily divided into two subspecies: ssp. annua which contains erect/ annual plants and ssp. reptans which consists of prostrate/perennial individuals ${ }^{3,12,18,19)}$. In Japan, however, ssp. reptans is rarely observed. This paper focuses on the spread of ssp. annua into diverse habitats.

The present study reports the variation in morphology and energy allocation pattern of $P$. annua populations in paddy fields, upland fields and pathways in arable lands, and the adaptive strategies of this species are discussed.

\section{Materials and Methods}

Six populations of $P$. annua were collected from three habitats, paddy fields, upland fields and pathways in two locations, Kyoto University and Kamigamo in Kyoto Prefecture, Japan. Those two locations are sufficiently distant from each other (about 7 $\mathrm{km})$ so that the gene flow of P. annua between the two locations is unlikely. The pathways lie between the paddy and the upland fields in both locations. The paddy field at Kyoto University had been cropped with wheat after rice cultivation for decades, while the other paddy field in Kamigamo had lain fallow in winter. The upland fields in both locations had been rotated with vegetables or wheat for winter cropping.

Seedlings with a few tillers of $P$. annua collected from their original habitats were grown at Kyoto University in 1985. When they reached a maturing stage, seeds were collected in bulk from every population. On February 7 in 1986, 20 seedlings extending the first leaf from every population were transplanted into polyvinyl pots $(100 \mathrm{ml})$ filled with commercial red loam (Shunpuh Tokotsuchi) containing chemical fertilizer, N 24.0, P 33.6, $\mathrm{K} 28.8 \mathrm{~kg} / \mathrm{ha}$. They were grown in a polyvinyl film house at Monsanto Agricultural Research Station in Ibaraki Prefecture.

Heading time of the first panicle of every individual was recorded. After plants were dug up and dried up at $80^{\circ} \mathrm{C}$ in June, morphology and the partitioning of dry matter into various organs were investigated. Seven morphological characters, plant length, culm length, panicle length and width, flag leaf length and width, and number of leaves were measured on the main stem for 20 plants of each population. Number of stems and seed (caryopsis) length and width were also recorded for every individual as well. The seed size of an individual was represented as the mean of 20 seeds sampled from each plant.

Mature seeds (caryopses) which were readily dropped with a slight touch of the hand were carefully collected every two days. The number of fertile and sterile seeds per plant was counted for 10 individuals of each population. The seed fertility of every individual was based on the ratio of fertile seed number/fertile and sterile seed number produced by an individual. Leaves, culms, axes of panicles and seeds were separately weighed for 20 plants from every population. Patterns of reproductive allocation were analyzed on a dry weight basis ${ }^{5}$.

\section{Results}

\section{Variation in morphology}

Morphology and growing behavior of $P$. 
annua greatly varied among the six populations (Table 1). Morphology of reproductive organs, panicle and seed (caryopsis), and flowering habits exhibited a variety of patterns peculiar to paddy field, upland field and pathway. The variation in patterns in those three habitats were seen most clearly in seed size (Fig. 1), and were similar in two different locations. Paddy field plants took a long time to head $(50.7 \pm 10.8$ to $51.3 \pm 8.4$ days after transplanting) with a large number of leaves on the main stem $(8.1 \pm 1.4$ to $8.7 \pm 1.3)$, and produced large panicles $(62.8 \pm 9.3$ to $67.1 \pm 9.0 \mathrm{~mm}$ in length) and large seeds (caryopses : $2.84 \pm 0.16$ to $2.96 \pm 0.20 \mathrm{~mm}$ in length). In contrast, it took a short time for upland field plants to head ( $34.9 \pm 2.8$ to $40.3 \pm$ 3.4 days) with a small number of leaves $(6.2 \pm$ 0.5 to $7.4 \pm 0.6$ ). Those plants produced small panicles ( $51.3 \pm 5.4$ to $53.9 \pm 7.2 \mathrm{~mm}$ ) and small

Table 1. Measurements of 11 characters (mean \pm standard deviation) in 6 Poa annua populations.

\begin{tabular}{|c|c|c|c|c|c|c|}
\hline \multirow{3}{*}{ Character } & \multicolumn{6}{|c|}{ Origin of populations } \\
\hline & \multicolumn{3}{|c|}{ Kyoto University } & \multicolumn{3}{|c|}{ Kamigamo } \\
\hline & $\begin{array}{l}\text { Paddy } \\
\text { field }\end{array}$ & $\begin{array}{l}\text { Upland } \\
\text { field }\end{array}$ & Pathway & $\begin{array}{l}\text { Paddy } \\
\text { field }\end{array}$ & $\begin{array}{l}\text { Upland } \\
\text { field }\end{array}$ & Pathway \\
\hline Plant length $(\mathrm{cm})$ & $40.7 \pm 5.8$ & $29.5 \pm 2.9$ & $27.2 \pm 2.8$ & $31.9 \pm 3.3$ & $32.6 \pm 6.0$ & $29.1 \pm 5.0$ \\
\hline Culm length $(\mathrm{cm})$ & $33.5 \pm 6.0$ & $24.3 \pm 2.6$ & $22.6 \pm 2.7$ & $24.9 \pm 4.0$ & $27.3 \pm 5.5$ & $24.4 \pm 4.9$ \\
\hline Panicle length (mm) & $67.1 \pm 9.0$ & $51.3 \pm 5.4$ & $46.9 \pm 6.6$ & $62.8 \pm 9.3$ & $53.9 \pm 7.2$ & $47.1 \pm 4.9$ \\
\hline Panicle width (mm) & $67.8 \pm 9.7$ & $47.0 \pm 5.5$ & $44.7 \pm 5.2$ & $66.8 \pm 15.4$ & $52.0 \pm 10.0$ & $47.5 \pm 5.4$ \\
\hline Flag leaf length (mm) & $31.4 \pm 16.1$ & $31.7 \pm 11.9$ & $23.3 \pm 13.3$ & $25.4 \pm 15.6$ & $37.9 \pm 25.7$ & $21.5 \pm 8.2$ \\
\hline Flag leaf width (mm) & $1.95 \pm 0.28$ & $1.85 \pm 0.40$ & $1.48 \pm 0.47$ & $1.88 \pm 0.46$ & $1.65 \pm 0.46$ & $1.57 \pm 0.39$ \\
\hline Caryopsis length $(\mathrm{mm})$ & $2.96 \pm 0.20$ & $2.30 \pm 0.16$ & $2.43 \pm 0.18$ & $2.84 \pm 0.16$ & $2.48 \pm 0.17$ & $2.52 \pm 0.14$ \\
\hline Caryopsis width (mm) & $0.92 \pm 0.06$ & $0.71 \pm 0.06$ & $0.77 \pm 0.05$ & $0.85 \pm 0.06$ & $0.76 \pm 0.05$ & $0.75 \pm 0.04$ \\
\hline Leaf number & $8.1 \pm 1.4$ & $6.2 \pm 0.5$ & $7.0 \pm 0.5$ & $8.7 \pm 1.3$ & $7.4 \pm 0.6$ & $7.9 \pm 0.5$ \\
\hline Stem number & $23.4 \pm 5.2$ & $33.5 \pm 4.4$ & $22.1 \pm 3.9$ & $30.8 \pm 13.1$ & $29.5 \pm 5.2$ & $28.0 \pm 4.0$ \\
\hline Days to heading & $50.7 \pm 10.8$ & $34.9 \pm 2.8$ & $46.9 \pm 5.5$ & $51.3 \pm 8.4$ & $40.3 \pm 3.4$ & $46.2 \pm 5.8$ \\
\hline
\end{tabular}

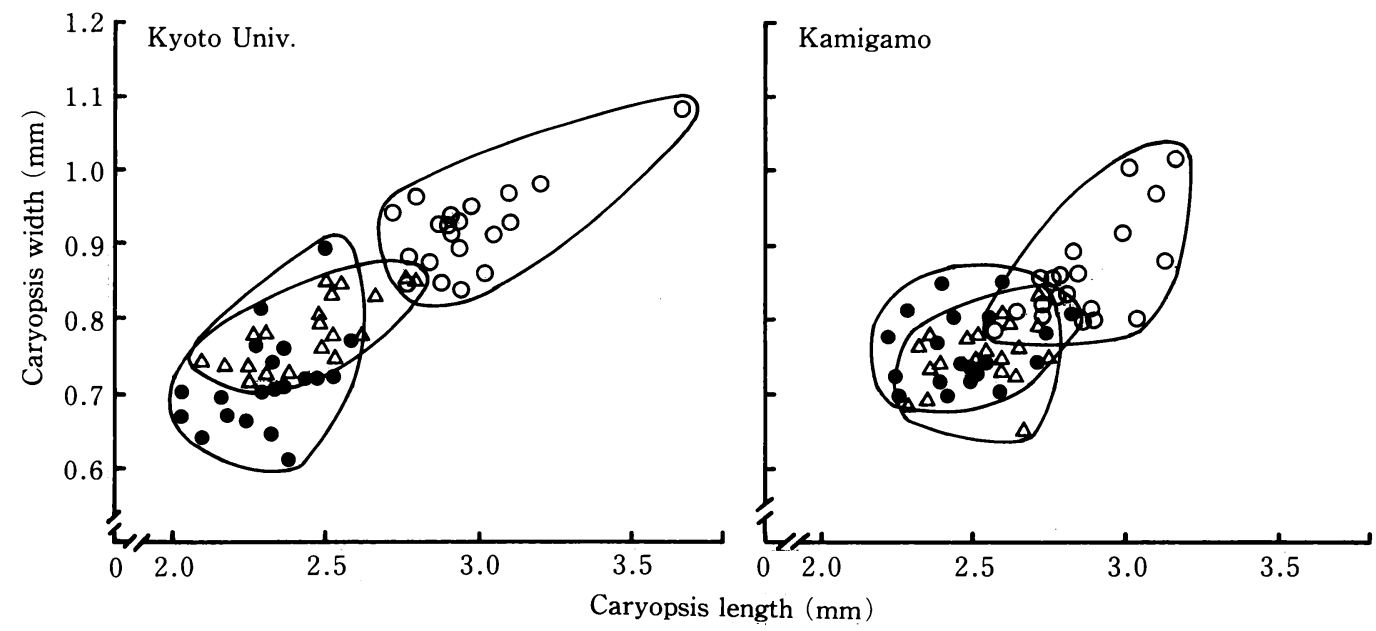

Fig. 1. Variation in caryopsis length and width in 6 Poa annua populations from two different locations.

(○) Paddy fields, (๑) Upland fields and $(\triangle)$ pathways. 
seeds $(2.30 \pm 0.16$ to $2.48 \pm 0.17 \mathrm{~mm})$. Pathway plants were intermediate between paddy field and upland field plants in heading time and leaf number on the main stem. The sizes in panicle and seed were as small as those of upland field plants.

\section{Variation in reproductive traits}

As shown in Table 2, mean seed fertility of the six populations was quite high, and varied in a narrow range from 72.5 to 78.5 in arcsin $\sqrt{ }(91.0$ to $96.1 \%)$.

Three correlations of plant biomass (total dry weight), reproductive allocation (RA: ratio of dry weight of total reproductive organs/total dry weight of plants) and seed number per plant, varied among these populations (Table 2). There was no clear correlation between RA and plant biomass in five populations except the Kamigamo upland field population, which showed a negative relationship. All three populations from Kyoto University exhibited positive correlations between seed number and RA, while they showed no clear relationship between

Table 2. Seed fertility and correlation coefficients among total dry weight (TDW), reproductive allocation (RA) and seed number per plant (SN) in 6 Poa annua populations.

\begin{tabular}{|c|c|c|c|c|}
\hline \multirow{2}{*}{ Population } & \multirow{2}{*}{$\begin{array}{c}\text { Fertility }^{\mathrm{a})} \\
(\text { Mean } \pm \text { S.D. })\end{array}$} & \multicolumn{3}{|c|}{ Correlation coefficients } \\
\hline & & RA-TDW ${ }^{\mathrm{b})}$ & SN-TDW ${ }^{c}$ & $\left.R A-S N^{d}\right)$ \\
\hline \multicolumn{5}{|l|}{ Kyoto Univ. } \\
\hline Paddy field & $74.7 \pm 2.5$ & 0.427 & 0.617 & $0.839^{* *}$ \\
\hline Upland field & $78.5 \pm 1.8$ & 0.263 & 0.261 & $0.749^{*}$ \\
\hline Pathway & $72.5 \pm 7.4$ & -0.105 & 0.386 & $0.720^{*}$ \\
\hline \multicolumn{5}{|l|}{ Kamigamo } \\
\hline Paddy field & $75.0 \pm 3.6$ & -0.107 & 0.067 & 0.514 \\
\hline Upland field & $75.4 \pm 4.2$ & $-0.585^{*}$ & 0.498 & 0.424 \\
\hline Pathway & $73.8 \pm 2.2$ & -0.190 & $0.715^{*}$ & $0.748^{*}$ \\
\hline
\end{tabular}

a) Data were transformed by $\arcsin \sqrt{ }$.

a) and $^{\text {b) }} \mathrm{n}=20$, $^{\text {c) }}$ and $^{\text {d) }} \mathrm{n}=10$.

${ }^{*, * *}$ : Significant at $\mathrm{p}<0.05$ and $\mathrm{p}<0.01$ level, respectively.
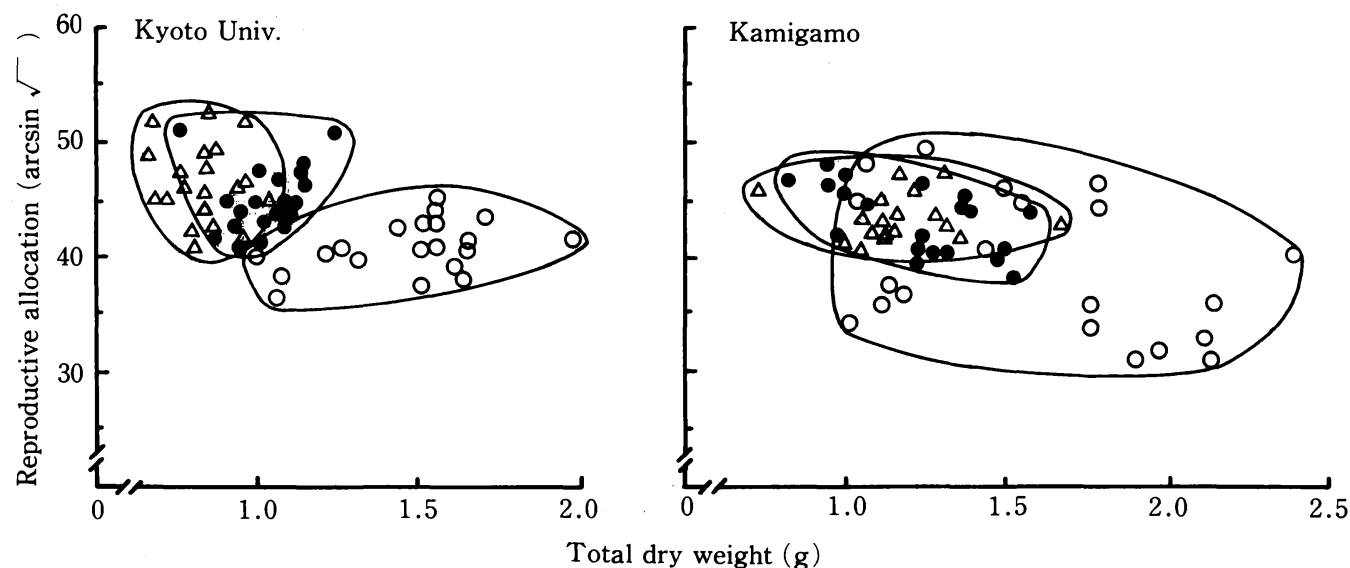

Fig. 2. Variation in reproductive allocation plotted against total dry weight in 6 Poa annua populations from two different locations.

Symbols as in Fig. 1. 
seed number per plant and plant biomass. Unlike those three populations from Kyoto University, the paddy and upland field populations from Kamigamo did not show any clear relationship between seed number per plant and RA or plant biomass, although the
Kamigamo pathway population had positive correlations between seed number per plant and RA or plant biomass.

Variation in RA on the basis of plant biomass (total dry weight) is shown in Fig. 2. Paddy field populations tended to exhibit

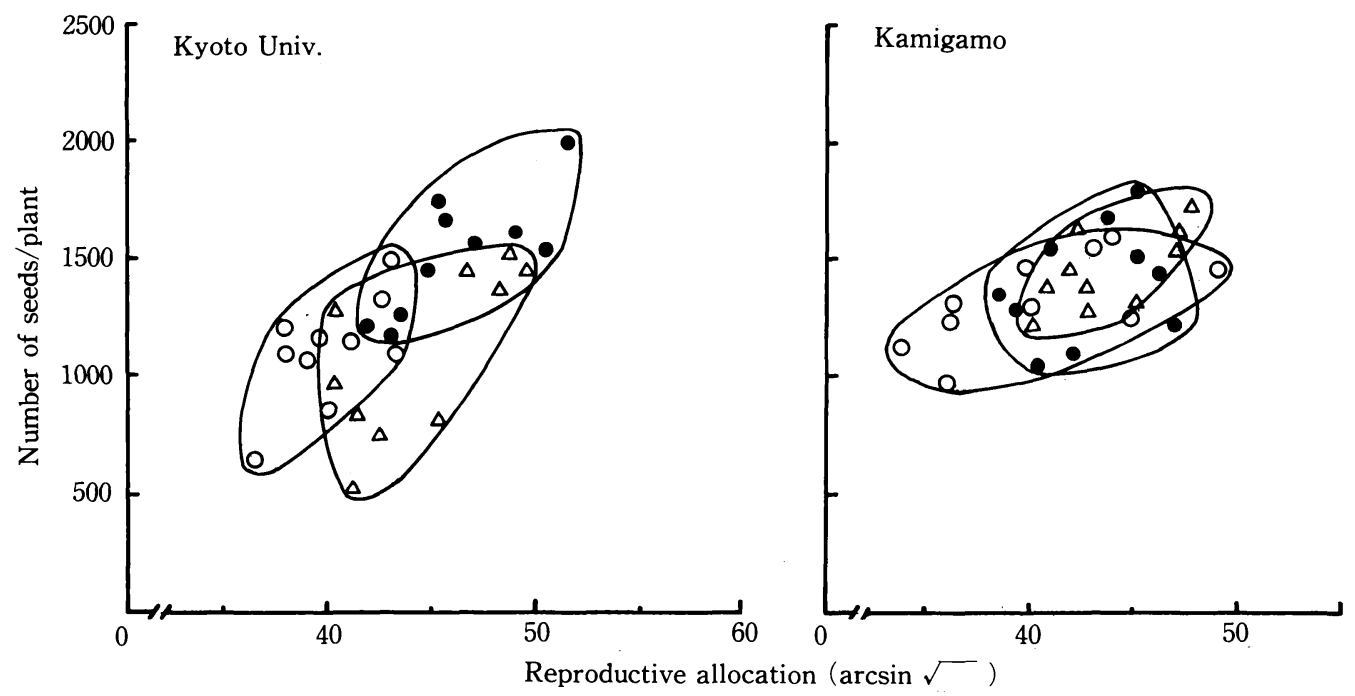

Fig. 3. Relationships between seed number per plant and reproductive allocation in 6 Poa annua populations from two different locations.

Symbols as in Fig. 1.

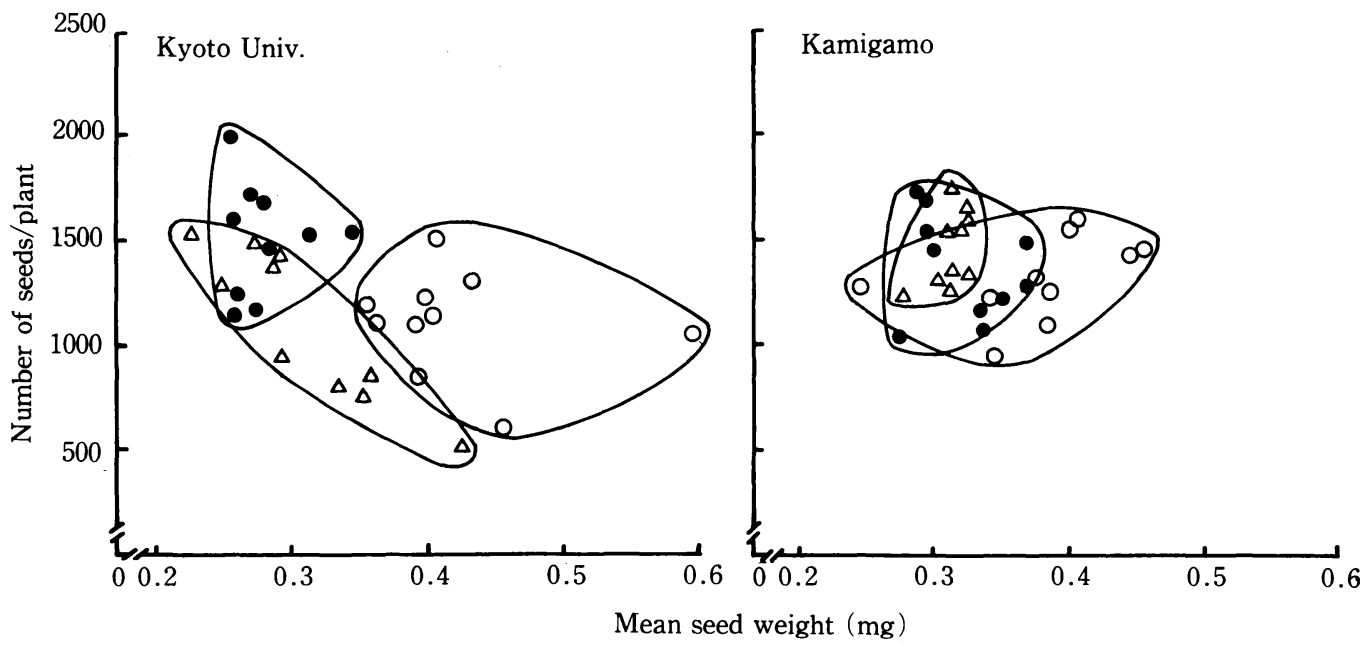

Fig. 4. Relationships between seed weight per grain and seed number per plant in 6 Poa annua populations from two different locations.

Symbols as in Fig. 1. 
lower RA (30 to 50 in $\arcsin \sqrt{ }: 25$ to $59 \%$ ) than upland field and pathway ones (38 to 52 in $\arcsin \sqrt{ }: 38$ to $62 \%$ ), although none of these three populations formed a striking contrast. This trend in RA between them was more obvious in the Kamigamo than in the Kyoto University. Plant biomass ranged from 0.6 to $2.5 \mathrm{~g}$. More than half of the individuals from paddy fields produced larger plant biomass (more than $1.5 \mathrm{~g}$ ) than upland field and pathway plants (less than about $1.5 \mathrm{~g}$ ).

Fig. 3 illustrates variation in seed number produced per plant on the basis of RA. Seed number per plant considerably overlapped throughout the six populations, varying from 500 to 2,000 .

Fig. 4 shows relationships between number of seeds per plant and mean seed weight per grain for six populations. No clear correlation between these two variables was observed in five of the populations, the exception being the pathway population in Kyoto University, which showed a negative correlation $\left(-0.891^{* *} ; \mathrm{p}<0.01\right)$. Paddy field plants generally produced heavier seeds $(0.35$ to $0.6 \mathrm{mg})$ than upland field individuals ( 0.25 to $0.38 \mathrm{mg}$ ). One of ten paddy field plants from Kamigamo exceptionally produced seeds as light as (about $0.25 \mathrm{mg}$ ) upland field ones. Pathway plants tended to be intermediate in seed weight between paddy and upland field plants.

\section{Discussion}

Morphological variation between the paddy and the upland field populations of $P$. annua was quite similar to that between the lowland and the upland types of Alopecurus aequalis var. amurensis ${ }^{14}$. The adaptive modes of the paddy and upland field populations of $P$. annua are assumed to be similar to those of $A$. aequalis var. amurensis. However, $P$. annua was greatly different in heading time from $A$. aequalis var. amurensis.
Upland field plants of $P$. annua headed more quickly than paddy field ones (11 to 15.8 days on average), while the heading time of the lowland type of $A$. aequalis var. amurensis was earlier than that of the upland type. The difference in variation pattern in heading time between those two species can be attributed to the difference in ecological niche in each habitat. The cultivation practices in paddy and upland fields may not always act on the flowering habit of plants as selection pressure to short-lived annual plants.

Intraspecific variation in energy allocation pattern and propagule output have been reported in several species ${ }^{9,12,17)}$. The number of propagules per perennial plant in closed woodland increased as RA increased, while annual and biennial plants exhibited no clear relationship between the number of propagules and $\mathrm{RA}^{7}$. Among annual plants, five Setaria species increased in number of propagules in response to plant biomass ${ }^{8}$. In the present study, all three populations of $P$. annua from Kyoto University increased in number of seeds in response to RA, just like perennials in woodland. The seed numbers of paddy and upland field populations in Kamigamo were independent of both RA and plant biomass. A pathway population in Kamigamo increased the number of seeds in response to both RA and plant biomass. Such intraspecific variation of $P$. annua in reproductive allocation pattern may indicate the various adaptive modes within a species.

The present analysis in morphology, flowering habit and reproductive trait strongly supports genecological differentiation of $P$. annua between paddy field and upland field populations. The similar adaptive modes to those of the lowland and the upland types of A. aequalis var. amurensis are assumed to be as follows. 
In paddy fields, winter annual weeds including $P$. annua quickly emerge after water is drained for the rice harvest in autumn; the main selection pressure on this species is thought to be the competition with other annual plants ${ }^{11,14)}$. Paddy field plants produced larger and heavier seeds from larger plant biomass, resulting in somewhat lower RA than upland field and pathway plants. Little dormancy and little light requirement for germination enable $P$. annua in paddy fields to emerge quickly after the drainage for rice harvest ${ }^{11)}$. Thus, the quick establishment of large seedlings from the large seeds is considered to be an adaptive trait to compete with other annual plants in fallow paddy fields.

Upland field populations are subjected to unpredictable mortality, i.e. irregular ploughing and weeding. They flowered quickly and produced small seeds, in contrast with paddy field plants. Upland field populations irregularly emerge under field conditions because of seed dormancy and strong light requirements for germination ${ }^{11}$. Those traits seem to have been adapted to avoid unpredictable risk of mortality caused by irregular ploughing and weeding.

In the concept of $\mathrm{r}$ - and $\mathrm{K}$-selection, the position of a population on a $r-K$ continuum is determined by the relationship between the propagule number per plant and the relative magnitude of density-dependent and densityindependent mortality ${ }^{2,15)}$. P. annua in this study exhibited no conspicuous difference in number of seeds produced by a plant between paddy and upland field populations (Fig. 3). Thus, the variation in seed number per plant between those two populations did not necessarily support the population differentiation based on $\mathrm{r}$ - and $\mathrm{K}$-selection. However, upland field plants tended to exhibit relatively higher RA than paddy field ones (Fig. 2).
The higher RA of upland field populations enables them to keep the high seed fecundity even when they are small in plant biomass. The lower RA of paddy field plants allows them to allocate more energy to vegetative parts, resulting in the increase of competitive ability. Therefore, the variation in reproductive allocation pattern observed between paddy and upland field populations appeared to readily support the adaptive differentiation to their habitats.

Acknowledgements: The senior author thanks Drs. J.L. Killmer, Monsanto Agricultural Group and S. Yamane, Monsanto Japan, Ltd. for their help and encouragement.

\section{References}

1) Gadgil, M. and W.H. Bossert 1970. Life historical consequences of natural selection. Amer. Natur. 104, 1-24.

2) Gadgil, M. and O.T. Solbrig 1972. The con cept of $\mathrm{r}^{-}$and $\mathrm{K}$-selection : evidence from wild flowers and some theoretical considerations. Amer. Natur. 106, 14-31.

3) Gibealt, V.A. and N.R. Goetze 1972. Annual meadow-grass. J. Sports Turf Res. 48, 9-19.

4) Harper, J.L. and J. Ogden 1970. The reproductive strategy of higher plants. I. The concept of strategy with special reference to Senecio vulugaris L. J. Ecol. 58, 681-698.

5) Hickman, J.C. and L.F. Pitelka 1975. Dry weight indicates energy allocation in ecological strategy analysis of plants. Oecologia 21, $117-121$.

6) Kawano, S. 1975 . The productive and reproductive biology of flowering plants. II. The concept of life history strategy in plants. J. Coll. Lib. Arts., Toyama Univ. Japan 8, 51-86.

7) Kawano, S. 1981. Trade-off relationships between some reproductive characteristics in plants with special reference to life history strategy. Bot. Mag. Tokyo 94, 285-294.

8) Kawano, S. and S. Miyake 1983 . The productive and reproductive biology of flowering 
plants. X. Reproductive energy allocation and propagule output of five congeners of the genus Setaria (Gramineae). Oecologia 57, 613.

9) Kobayashi, H. and K. Ueki 1983. Phenotypic variation and adaptation in Eleocharis kurog. uwai Ohwi, a paddy perennial Cyperaceous weed. Weed Res., Japan 28, 179-186.

10) Kobayashi, H., M. Itoh and K. Ueki 1983. Variation in Poa annua. Phenotypic variation among playing areas of a golf course. Weed Res., Japan 28 (Suppl.), 149-150 (in Japanese).

11) Kobayashi, H., Y. Motomura and K. Ueki 1988. Difference in seed germination of lowland and upland types in Poa annua. Weed Res., Japan 33 (2), 145-147 (in Japanese).

12) Law, R., A.D. Bradshaw and P.D. Putwain 1977. Life-history variation in Poa annua. Evolution 31, 233-246.

13) Lush, W.M. 1989. Adaptation and differentiation of golf course populations of annual bluegrass (Poa annua). Weed Sci. 37, 54-59.

14) Matumura, M. 1967. Genecological studies on the foxtail grass, Alopecurus aequalis, in Japan. Res,Bull. Fac. Agric. Gifu Univ. Japan 25, 129208 (in Japanese with English summary).

15) Pianka, E.R. 1970. On $\mathrm{r}^{-}$and K-selection. Amer. Natur. 104, 592-597.

16) Sakamoto, S. 1961. An early ecotype of Agropyron tsukushiense var. transiense. Seiken Ziho 12, 45-58 (in Japanese with English summary).

17) Solbrig, O.T. and B.B. Simpson 1974. Components of regulation of a population of dandelions in Michigan. J. Ecol. 62, 473-486.

18) Warwick, S.I. 1979. The biology of Canadian weed. 37. Poa annua L. Can. J. Plant Sci. 59, 1053-1066.

19) Warwick, S.I. and D. Briggs 1978. The genecology of lawn weeds. I. Population differentiation in Poa annua $\mathrm{L}$. in a mosaic environment of bowling green lawns and flower beds. New Phytol. 81, 711-724.

\section{農耕地におけるスズメノカタビラの形態および 繁殖体投資率と繁殖体生産における变異}

伊藤松雄 ${ }^{*}$ ・ 小林央往 ${ }^{* *} \cdot$ 植木邦和 $* * *$

\section{摘 要}

二つの異なる地点の水田, 畑地および路傍に由来 するスズメノカタビラ (Poa annua L.) 計 6 集団に ついて，それぞれの生育地への適応戦略を明らかに するために, 形態および繁殖体へのエネルギー投資 様式における集団変異を調查した。

個体あたりの種子数と繁殖体投資率 (RA) あるい はその種子数と全乾物重との相関において, 集団間 に大きな変異が認められた(第 2 表, 第 3 図)。ある 地点の水田, 畑地, 路傍由来の全集団では, 種子数 とRA に正の相関が認められた。もう一方の地点の 水田, 畑地由来集団では, 個体あたり種子数は繁殖

\footnotetext{
*日本モンサント (株) 生物科学研究所

** 山口大学農学部

*** 石川農業短期大学
}

体投資率あるいは全乾物重のどちらにも有意な相 関を示さなかったが，これらに隣接する路傍由来集 団では, 個体あたり種子数は繁殖体投資率と全乾物 重の両方に正の相関を示した。

水田由来集団は出穂が遅く, かつ主秙葉数が大き くなった(第 1 表)。この集団の個体は大きな植物体 から大きくかつ重い種子を生産し, 繁殖体投資率 (RA) は低くなる傾向を示した(第 $1,2,4$ 図)。それ とは対照的に, 畑地由来の集団は出穂が早く, 主稈 葉数も少なかった。この集団の個体は植物体重が小 さく，小さな軽い種子を生産し，その結果 RA 值は 高くなる傾向を示した。路傍由来集団は水田および 畑地由来集団の中間的な特徵を示した。畑地由来集 団の繁殖特性は, 畑地の作物生産に付随する不規則 な耕起に適応的であると推察された。一方, 水田由 来集団は水田裏作における作物あるいは雑草との 競合に適応的であると考察された。

キーワード : スズメノカタビラ, 適応, 水田, 繁殖 体投資率, 畑地 